\title{
ОСОБЛИВОСТІ ЗМІНИ ПОКАЗНИКІВ ПРОЗАПАЛЬНИХ ЦИТОКІНІВ У ЩУРІВ ІЗ МОДЕЛЬОВАНИМ ГАЛАКТОЗАМІНОВИМ ГЕПАТИТОМ НА ТЛІ МЕРКАЗОЛІЛІНДУКОВАНОГО ГІПОТИРЕОЗУ
}

\section{Особливості зміни показників прозапальних цитокінів у щурів із модельованим галактозаміновим гепатитом на тлі мерказоліліндукованого гіпотиреозу \\ О. Й. Зарічна, Х. І. Шкляр, І. М. Кліщ}

Тернопільський національний медичний університет імені І. Я. Горбачевського

Резюме. Як відомо, гіпофрункція щитоподібної залози (ЩЗ) часто поєднується із різними захворюваннями гепатобіліарної системи. Гормони щз регулюють рівень базального метаболізму в усіх клітинах, включаючи гепатоцити, що впливає на фрункціонування печінки, а вона, у свою чергу, метаболізує тиреоїдні гормони, тим самим регулює їх системні ендокринні ефректи. Порушення фрункції щитоподібної залози можуть призводити до змін функцій печінки, а при ії захворюваннях - виникають відхилення у метаболізмі тиреоїдних гормонів. Важлива роль у патогенезі обох захворювань належить цитокіновим механізмам та порушенню фрункціонального стану ендотелію.

Мета дослідження - вивчити зміни показників цитокінового профрілю та фрункціонального стану ендотелію у щурів із мерказоліліндукованим гіпотиреозом і супутнім галактозаміновим гепатитом.

Матеріали і методи. Дослідження проводили на білих щурах-самцях масою тіла 180-200 г, яких отримали з віварію Тернопільського національного медичного університету імені І. Я. Горбачевського мОЗ України. Гіпотиреоз моделювали щоденним введенням фрармакопейного тиреостатика мерказолілу в дозі 25 мг/кг протягом 21-ї доби per os за допомогою спеціального зонда. Вплив гіпотиреозу на перебіг запального процесу при гепатиті вивчали на моделі галактозамінового гепатиту (ГАГ), який викликали шляхом внутрішньочеревного уведення експериментальним тваринам галактозаміну в дозі 400 мг/кг у вигляді $20 \%$ розчину.

Результати. Виявлено, що показник TNF- $\alpha$ у тварин із модельованим гіпотиреозом збільшився у 1,05 раза, IL-1 $\alpha$ - в 1,41 раза, IL-4 - 1,33 раза, INF-y - 5,56 раза відносно інтактних тварин. Причому моноцитарний хемоатрактантний протеїн (МСР) зменшився у 0,95 раза. Після модельованого галактозамінового гепатиту ви-

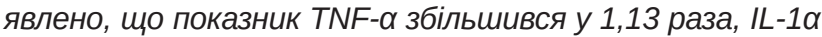
- в 1,49 раза, IL-4 - 1,56 раза, INF-y - 6,57 раза, MCP _ 1,06 раза відносно інтактних тварин. Після модельова(๐). Й. Зарічна та ін., 2019
Peculiarities of the change in the indicators of proinflammatory cytokines in rats with modeled galactosamine hepatitis on the background of mercazolil-induced hypothyroidism

O. Y. Zarichna, Kh. I. Shkliar, I. M. Klishch

I. Horbachevsky Ternopil National Medical University e-mail: zarichnaoi@tdmu.edu.ua

Summary. It is known that thyroid hypofunction is often combined with various diseases of the hepatobiliary system. The thyroid hormones regulate the level of basal metabolism of all cells, including hepatocytes, which affects the functioning of the liver, and the liver, in turn, metabolizes thyroid hormones, thereby regulating their systemic endocrine effects. Disorders of the thyroid gland can lead to changes in the functions of the liver, and in liver disease may cause deviations in the metabolism of thyroid hormones. Cytokine mechanisms and endothelial dysfunction play an important role in the pathogenesis of both diseases.

The aim of the study - to investigate changes in cytokine profile and functional status of endothelium in rats for mercazolil-induced hypothyroidism with concomitant galactosamine hepatitis.

Materials and Methods. The studies were performed on white male rats weighing 180-200 g obtained from vivarium of I. Horbachevsky Ternopil National Medical University. Hypothyroidism was modeled by daily administration of per os using a special probe of mercazolil pharmacopoeial thyrostatics at a dose of $25 \mathrm{mg} / \mathrm{kg}$ for 21 days. The effect of hypothyroidism on the course of the inflammatory process in hepatitis was studied in a model of galactosamine hepatitis (GAH), which was caused by intraperitoneal administration to experimental animals galactosamine at a dose of $400 \mathrm{mg} / \mathrm{kg}$ in the form of a $20 \%$ solution.

Results. It was found that the TNF- $\alpha$ index in animals with simulated hypothyroidism increased by 1.05 times, IL 1- $\alpha$ - by 1.41 times, IL-4 - 1.33 times, INF-y -5.56 times relative to intact animals. Moreover, monocyte chemoattractant protein (MCP) decreased by 0.95 times. After simulated galactosamine hepatitis, it was found that TNF- $\alpha$ increased by 1.13 times, IL-1 $\alpha-1.49$ times, IL-4 - 1.56 times, INF- $y-6.57$ times MCP - 1.06 times relatively intact animals. Following the simulated galactosamine hepatitis, the following changes occurred 
ного галактозамінового гепатиту на тлі гіпотиреозу відбулись наступні зміни: показник TNF- $\alpha$ збільшився у 1,32 раза, IL-1 $\alpha$ - в 1,70 рази, IL-4 - 1,94 раза, INF-y - 5,89 раза МСР - 1,11 раза відносно інтактних тварин.

Висновки. За умов експериментального галактозамінового гепатиту на тлі гіпотиреозу відбуваєть-

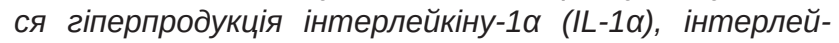
кіну-4 (IL-4), інтерферону-у (IFN-y), фрактора некрозу пухлин- $\alpha$ (TNF- $\alpha$ ), а також гіпопродукцію моноцитарного хемоатрактантного протеїну, що можуть спричиняти значні зміни в тканинах печінки.

Ключові слова: галактозаміновий гепатит; гіпотиреоз; цитокіни; IFN-y; IL-1 $\alpha$; IL-4; MCP; TNF- $\alpha$.

\section{ВСТУП}

Гіпотиреоз є однією із найпоширеніших патологій щитоподібної залози (ЩЗ), яку діагностують від 1,4 до 8,0 \% людей у загальній популяції, та має тенденцію до подальшого зростання [1]. Висока частота захворювань щз залежить від багатьох причин, серед яких найвагомішими вважають припинення централізованої йодної профрілактики, техногенне забруднення довкілля, негативні зміни у структурі харчування значної частини населення за нових соціально-економічних умов [6, 8, 9]. Гіпофрункція щитоподібної залози часто поєднується із різними захворюваннями гепатобіліарної системи.

Гормони щз регулюють рівень базального метаболізму в усіх клітинах, включаючи гепатоцити, що впливає на фрункціонування печінки, а вона, у свою чергу, метаболізує тиреоїдні гормони, тим самим регулює їх системні ендокринні ефекти [1, 12]. Порушення фрункції щитоподібної залози можуть призводити до змін їі ффункцій, а при захворюваннях - виникають відхилення у метаболізмі тиреоїдних гормонів [5]. Печінці належить центральна роль у дейодуванні ТГ з утворенням їх активних або інактивованих форм [2]. Відомо, що в кишечнику не лише всмоктується йод, що міститься в їжі, але й відбувається повторне його всмоктування, який вивільняється в печінці у результаті дейодування тиреоїдних гормонів (ТГ). Тому цілком зрозуміло, що розлад діяльності гепатобіліарної системи може відбитися на метаболізмі цих гормонів.

Дані літератури також свідчать про те, що на тлі вторинної імунної недостатності при дисорункції щитоподібної залози ускладнюється перебіг інших патологічних процесів, при цьому ступінь і вираження патологічного процесу залежать від тяжкості та тривалості гіпотиреозу [10].

Запальний процес, що виникає на тлі гіпотиреозу, характеризується зниженням активності клітин, що беруть участь у фрормуванні імунної відповіді організму.

Важлива роль у патогенезі обох захворювань належать цитокіновим механізмам та порушенню фрункціонального стану ендотелію [2]. on the background of hypothyroidism: TNF- $\alpha$ increased 1.32-fold, IL-1 $\alpha$ - 1.70-fold, IL-4 - 1.94-fold, INF-y - 5.89fold MCP - 1.11 times relative to intact animals.

Conclusions. It is concluded that under the conditions of experimental galactosamine hepatitis, hypothyroidism overproduces interproduction of interleukin-1a (IL-1 $\alpha$ ), interleukin-4 (IL-4), interferon-y (IFN-y), tumor necrosis factor- $\alpha$ (TNF- $\alpha)$, as well as hypoproduction of monocytic chemoattractant protein (MCP), which can cause significant changes in liver tissues.

Key words: galactosamine hepatitis; hypothyroidism; cytokines; IFN-y; IL-1 $\alpha$; IL-4; MCP; TNF- $\alpha$.

Протягом останніх 15 років активно вивчають молекули, що утворюються клітинами для міжклітинного взаємозв'язку та взаєморегуляції їх діяльності. Такі молекули називають цитокінами. Сьогодні під цитокінами розуміють велику кількість різноманітних біологічно активних молекул білкової природи, що секретуються клітинами імунної системи при запаленні, імунній відповіді, гемопоезі тощо [14-16].

Цитокіни $€$ найбільш універсальною системою регуляції, що здатна проявляти біологічну активність як дистанційно, так і при міжклітинному контакті. Цитокіни є системою-організатором організму, яка фрормує та регулює весь комплекс патоморфологічних зсувів при проникненні патогена [14-17]. Синтезуючись у вогнищі запалення, вони впливають практично на усі клітини, які беруть участь у вогнищі запалення, а також практично на усі клітини, які беруть участь у розвитку запалення, включаючи гранулоцити, макрофраги, фрібробласти, клітини ендотелію, епітелію, Т- та В-лімфроцити [17, 18].

Одним 3 агентів, що сприяє надходженню моноцитів із кровоносного русла в печінкову тканину та їх акумуляції, є моноцитарний хемоатрактантний протеїн (МСР). МСР - це потужний хемокін, який проявляє найвираженіший хемотаксичний ефект щодо моноцитів і Т-лімфроцитів. Окрім забезпечення трансміграції циркулюючих моноцитів у тканини, МСР характеризується цілим спектром ефектів на ці клітини, який включає як індукцію секреції супероксид-аніона та цитокінів, так і стимуляцію експресії адгезивних молекул. Біосинтез МСР відбувається в моноцитах, ендотеліальних, мезангіальних і гладком'язових клітинах під впливом цитокінів і окиснених ліпопротеїнів низької щільності [18]. Саме тому відбувається його гіпопродукція.

Також відомо, що гіперпродукція IL-1 $\alpha$, IL-4, IFN-y, TNF- $\alpha$ можуть спричиняти значні зміни в тканинах печінки [17].

Метою дослідження було дослідження змін показників цитокінового профрілю та функціонального стану ендотелію у щурів із мерказоліліндукованим гіпотиреозом і супутнім галактозаміновим гепатитом. 


\section{МАТЕРІАЛИ I МЕТОДИ}

Дослідження проводили на білих щурах-самцях масою тіла 180-200 г, яких отримали 3 віварію Тернопільського національного медичного університету імені І. Я. Горбачевського МОЗ України, відповідно до вимог Правил проведення робіт 3 використанням експериментальних тварин [7]. Тварини перебували на повноцінному раціоні віварію із вільним доступом до води. Гіпотиреоз моделювали щоденним введенням фрармакопейного тиреостатика мерказолілу («Здоров'я», Україна) у дозі 25 мг/кг протягом 21-ї доби per os за допомогою спеціального зонда [11]. Контроль здійснювали за рівнем тироксину, трийодтироніну і тиреотропного гормону, а також за масою тварин і їх руховою активністю. До групи порівняння входили тварини, яким мерказоліл не вводили. Вплив гіпотиреозу на перебіг запального процесу при гепатиті вивчали на моделі галактозамінового гепатиту (ГАГ), який викликали шляхом внутрішньочеревного уведення експериментальним тваринам галактозаміну в дозі 400 мг/кг у вигляді 20 \% розчину. Через 1-шу і 7-му доби після моделювання гепатиту щурів декапітували під тіопенталовим наркозом (50 мг/кг). Групами порівняння були тварини з експериментальним гіпотиреозом і щури з токсичним галактозаміновим гепатитом. Контролем слугував матеріал від інтактних тварин.
Вивчення показників цитокінового профрілю проводили методом імуноферментного аналізу, визначаючи вміст у плазмі крові прозапальних цитокінів IL-1 $\alpha$, MCP, TNF- $\alpha$ та протизапальних IFN-y, IL-4. Дане дослідження проводили за допомогою імуноферментного аналізатора «Stat-fax 303», проточного цитофрлуориметра «Becman Culter Epix XL», згідно з інструкціями.

Отримані цифрові дані обробляли методом варіаційної статистики. Обробку результатів виконано у відділі системних статистичних досліджень. Для усіх показників розраховували значення середньої арифметичної вибірки (М), її дисперсії і помилки середньої (m). Достовірність різниці значень між незалежними кількісними величинами визначали при нормальному розподілі за критерієм Стьюдента, в інших випадках - за допомогою U-критерію Мана-Уїтні. Аналіз кореляційних зв'язків отриманих результатів проводили 3 використанням критерію Спірмена [4].

\section{РЕЗУЛЬТАТИ ТА ОБГОВОРЕННЯ}

У результаті дослідження ми встановили, що модельований галактозаміновий гепатит порізному впливав на показники цитокінового профрілю. Істотні зміни відбулися як у тварин зі збереженою, так і зниженою фрункціями щитоподібної залози (табл.).

\begin{tabular}{|c|c|c|c|c|}
\hline \multirow[b]{2}{*}{ Показник } & \multicolumn{4}{|c|}{ Група тварин } \\
\hline & $\begin{array}{c}\text { інтактні тварини } \\
(\mathrm{n}=3)\end{array}$ & $\begin{array}{l}\text { гіпотиреоз } \\
(\mathrm{n}=7)\end{array}$ & $\begin{array}{l}\text { галактозаміновий гепатит } \\
\qquad(\mathrm{n}=7)\end{array}$ & $\begin{array}{c}\text { гепатит+гіпотиреоз } \\
(\mathrm{n}=7)\end{array}$ \\
\hline TNF- $\alpha$ (пг/мл) & $2,77 \pm 0,08$ & $\begin{array}{c}2,90 \pm 0,19 \\
p<0,05\end{array}$ & $\begin{array}{c}3,14 \pm 0,23 \\
p<0,001 \\
p_{1}<0,001\end{array}$ & $\begin{array}{c}3,67 \pm 0,17 \\
p<0,01 \\
p_{1}<0,05 \\
p_{2}>0,05\end{array}$ \\
\hline IL-1 $\alpha$ (пг/мл) & $4,07 \pm 0,25$ & $\begin{array}{c}5,74 \pm 0,43 \\
p<0,05\end{array}$ & $\begin{array}{c}6,06 \pm 0,54 \\
p<0,001 \\
p_{1}<0,001\end{array}$ & $\begin{array}{c}6,91 \pm 0,20 \\
p<0,01 \\
p_{1}<0,05 \\
p_{2}>0,05\end{array}$ \\
\hline IL-4 (пг/мл) & $1,6 \pm 0,10$ & $\begin{array}{c}2,13 \pm 0,19 \\
p<0,05\end{array}$ & $\begin{array}{c}2,49 \pm 0,16 \\
p<0,001 \\
p_{1}<0,001\end{array}$ & $\begin{array}{c}3,11 \pm 0,19 \\
p<0,01 \\
p_{1}<0,05 \\
p_{2}>0,05\end{array}$ \\
\hline INF-y (пг/мл) & $0,63 \pm 0,15$ & $\begin{array}{c}3,50 \pm 0,29 \\
p<0,05\end{array}$ & $\begin{array}{c}4,14 \pm 0,23 \\
p<0,001 \\
p 1<0,001\end{array}$ & $\begin{array}{c}3,71 \pm 0,21 \\
p<0,01 \\
p_{1}<0,05 \\
p_{2}>0,05\end{array}$ \\
\hline MCР (пг/мл) & $21,0 \pm 0,84$ & $\begin{array}{c}19,93 \pm 1,04 \\
p<0,05\end{array}$ & $\begin{array}{c}22,29 \pm 0,92 \\
p<0,001 \\
p 1<0,001\end{array}$ & $\begin{array}{c}23,36 \pm 0,53 \\
p<0,01 \\
p_{1}<0,05 \\
p_{2}>0,05\end{array}$ \\
\hline
\end{tabular}

Примітки: 1) р - достовірність різниці тварин експериментальних груп відносно інтактних тварин

2) $p_{1}$ - достовірність різниці тварин експериментальних груп відносно гіпотиреоїдних тварин;

3) $p_{2}-$ достовірність різниці еутиреоїдних і гіпотиреоїдних тварин із гострим гепатитом. 
Так, показник TNF- $\alpha$ у тварин із модельованим гіпотиреозом збільшився у 1,05 раза, IL-1 $\alpha$ - в 1,41 раза, IL-4 - у 1,33 раза, INF-y - в 5,56 раза відносно інтактних тварин. Причому МСР зменшився у 0,95 раза.

Після модельованого галактозамінового гепатиту виявлено, що показник TNF- $\alpha$ збільшився у 1,13 раза, IL-1 $\alpha$ - в 1,49 раза, IL-4 - у 1,56 раза, INF-y - в 6,57 раза, MCP - 1,06 раза відносно інтактних тварин.

Також виявлено, що після модельованого галактозамінового гепатиту на тлі гіпотиреозу відбулись наступні зміни: показник TNF- $\alpha$ збільшився у

\section{СПИСОК ЛІТЕРАТУРИ}

1. Герок В. В. Захворювання печінки і жовчовивідної системи / В. В. Герок, Е. Х. М. Блюм. - МЕДпрессінформ, 2009. - 199 с.

2. Макар Р. Д. Гіпотиреоз: концептуальні аспекти крізь призму часу / Р. Д. Макар, М. В. Сандурська // Міжнар. ендокринол. журн. - 2009. - № 1. - С. 124-131.

3. Макар Р. Д. Післяопераційний гіпотиреоз: тяжке ускладнення чи прогнозований наслідок лікування / Р. Д. Макар // Міжнар. ендокри-нол. журнал. - 2010. № 1 (25). - C. 90-95.

4. Лапач С. Н. Статистические методы в медико-биологических исследованиях с использованием Excel / С. Н. Лапач, А. В. Чубенко, П. Н. Бабич. - К. : Морион, 2000. $-320 \mathrm{c}$.

5. Науково-практичні рекомендації з утримання лабораторних тварин та роботи з ними / Ю. М. Кожем'якін, О. С. Хромов, М. А. Філоненко, Г. А. Сайоретдінова. - К. : Авіцена, 2002. - 156 с.

6. Паньків В.І. Практична тиреоїдологія / В.І.Паньків. - Донецьк : Видавець О. Ю. Заславський, 2011. $224 \mathrm{c}$.

7. Паньків В. І. Синдром гіпотиреозу / В. І. Паньків // Міжнар. ендокринол. ж. - 2012. - № 5. - С. 83-87.

8. Серцево-судинний ризик на тлі дисфункції щитоподібної залози / О. І. Мітченко, В. Ю. Романов, А. О. Логвиненко [та ін.] // Укр. кардіол. журнал. - 2011. - № 5. - C. 23-29.

9. Тимченко А. М. Динаміка розповсюдження тиреоїдної патології серед населення в регіонах з різним ступенем йодного дефріциту та напрямки профрілактики / А. М. Тимченко, К. В. Місюра // Международный эндокринологический журнал. - 2007. - № 3(9).

10. Isman C. A. Methimazole-induced hypothyroidism in rats ameliorates oxidative injury inexperimental colitis /
1,32 раза, IL-1 $а$ - в 1,70 рази, IL-4 - у 1,94 раза, INF-y - в 5,89 раза, MCP - 1,11 раза відносно інтактних тварин.

\section{ВИСНОВКИ}

За умов експериментального галактозамінового гепатиту на тлі гіпотиреозу відбуваєть-

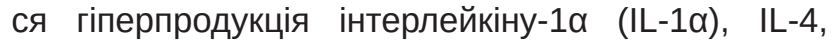
інтерферону-у (IFN-y), фрактора некрозу пухлин- $\alpha$ (TNF- $\alpha$ ), а також гіпопродукцію моноцитарного хемоатрактантного протеїну (МСР), що можуть спричиняти значні зміни в тканинах печінки.

C. A. Isman, B. C. Yegen, I. Alican // J. Endocrinol. - 2003. - Vol. 177, No. 3. - P. 471-476.

11. Tesch G. H. MCP-1/CCL2: a new diagnostic marker and therapeutic target for progressive renal injury in diabetic nephropathy / G. H. Tesch // Am. J. Physiol. Renal Physiol. - 2008. - Vol. 294. - P. 697-701.

12. Karmisholt J. Variation in thyroid function tests in patients with stable untreated subclinical hypothy-roidism / J. Karmisholt, S. Andersen, P. Laurberg // Thyroid. - 2008. - Vol. 18. - P. 303-308.

13. Laukkarinen J. The underlying mechanisms: how hypothyroidism affects the formation of common bile duct stones-a review / J. Laukkarinen, J. Sand, I. Nordback // HPB Surg. - 2012. - Vol. 45. - P. 70-74.

14. Tumor necrosis factor polymorphisms and alcoholic liver disease: A HuGE Review and Meta-Analysis / M. Marcos, M. Gómez-Munuera, I. Pastor [et al.] // American Journal of Epidemiology. - 2009. - No. 8. - P. 948-956.

15. Cui W. Mechanism of the transforming growth factorbeta induction of fibronectin expression in hepatic stem-like cells / W. Cui, H. B. Jin, Z. W. Li // Brazilian Journal of Medecal and Biological Research. - 2010. - No. 1. - P. 36-42.

16. Meyer C. TGF-beta signaling in alcohol induced hepatic injury / C. Meyer, N. M. Meindl-Beinker, S. Dooley // Front Bioscience. - 2010. - No. 1. - P. 740-749.

17. Analysis of immunohistochemical expression of proinflammatory cytokines (IL-1 $\alpha$, IL-6, and TNF- $\alpha$ ) in gallbladder mucosa: comparative study in acute and chronic calculous cholecystitis / A. Kasprzak, M. Szmyt, W. Malkowski [et al.] // Folia Morphol. - 2015. - Vol. 74 (1). - P. 65-72.

18. The cytokine profile in the patients with acute calculous cholecystitis and correction of its disorders / D. N. Gadzhiev, É. G. Tagiev, A. G. Guseǐnaliev [et al.] // Klin. Khir. - 2013. - Vol. 4. - P.17-19.

\section{REFERENCES}

1. Gerok VV, Blium EXM. Diseases of the liver and biliary system. [Захворювання печінки і жовчовивідної системи] MEDPress-inform; 2009. Ukrainian.

2. Makar RD, Sandurska MV. [Hypothyroidism: conceptual aspects through the prism of time]. Mizhnar endokrynol zhurn. 2009;1: 124-31. Ukrainian.

3. Makar RD. [Postoperative hypothyroidism: a serious complication or a predictable consequence of treatment]. Mizhnar endokrynol zhurn. 2010;1: 90-5. Ukrainian.

4. Lapach SN, Chubenko AV, Babych PN. Statistical methods in biomedical research using Excel. [Статистические методы в медико-биологических исследованиях с использованием Excel] Kyiv: Morion; 2001. Ukrainian.

5. Kozhemikin YuM, Khromov OS, Filonenko MA, 
Saifetdinova HA. Scientific and practical recommendations for keeping and working with laboratory animals. [Науковопрактичні рекомендації з утримання лабораторних тварин та роботи з ними] Kyiv: Avitsenna; 2002. Ukrainian.

6. Pankiv VI. Practical thyroidology. [Практична тиреоїдологія] Donetsk: Publisher Zaslavskyi O.Yu.; 2011. Ukrainian.

7. Pankiv VI. [Hypothyroidism syndrome]. Mizhnar endokrynol zhurn. 2012;5: 83-7. Ukrainian.

8. Mitchenko OI, Romanov VYu, Lohvynenko AO, Hvozdyk MV. [Cardiovascular risk on the background of thyroid dysfunction]. Ukr kardiol zhurn. 2011;5: 23-9. Ukrainian.

9. Tymchenko AM, Misiura KV [Dynamics of thyroid pathology prevalence among the population in regions with varying degrees of iodine deficiency and directions of prevention]. Mizhnar endokrynol zhurn. 2007;3: 9. Ukrainian.

10. Isman CA, Yegen BC, Alican I. Methimazoleinduced hypothyroidism in rats ameliorates oxidative injury inexperimental colitis. J Endocrinol. 2003;3: 471-6. DOI: 10.1677/joe.0.1770471.

11. Tesch GH. MCP-1/CCL2: a new diagnostic marker and therapeutic target for progressive renal injury in diabetic nephropathy. Am J Physiol Renal Physiol. 2008;294, 697701. DOI: 10.1152/ajprenal.00016.2008.

12. Karmisholt J, Andersen S, Laurberg P. Variation in thyroid function tests in patients with stable untreated subclinical hypothyroidism. Thyroid. 2008;18: 303-8. DOI: 10.1089/thy.2007.0241.

13. Laukkarinen J, Sand J, Nordback I. The underlying mechanisms: how hypothyroidism affects the formation of common bile duct stones-a review. HPB Surg. 2012;45: 704. DOI: $10.1155 / 2012 / 102825$.

14. Marcos M, Gómez-Munuera M, Pastor I. Tumor necrosis factor polymorphisms and alcoholic liver disease: A HuGE review and meta-analysis. American Journal of Epidemiology. 2009;8: 948-56. DOI: 10.1093/aje/kwp236.

15. Cui W, Jin HB, Li ZW. Mechanism of the transforming growth factor-beta induction of fibronectin expression in hepatic stem-like cells. Brazilian Journal of Medecal and Biological Research. 2010;1: 36-42. DOI: 10.1590/S0100879X2009007500017.

16. Meyer C, Meindl-Beinker NM, Dooley S. F-beta signaling in alcohol induced hepatic injury. Front Bioscience. 2010;1: 740-9. DOI: 10.1007/s00441-011-1246-y.

17. Kasprzak A, Szmyt M, Malkowski W. Analysis of immunohistochemical expression of proinflammatory cytokines (IL-1 $\alpha, I L-6$, and TNF- $\alpha$ ) in gallbladder mucosa: comparative study in acute and chronic calculous cholecystitis. Folia Morphol. 2015;74(1): 65-72. DOI: 10.5603/fm.2015.0011.

18. Gadzhiev DN, Tagiev EG, Guseǐnaliev AG. [The cytokine profile in the patients with acute calculous cholecystitis and correction of its disorders]. Klin khir. 2013;4: 17-19.

Отримано 10.09.19 